\title{
Penilaian Kriteria Green Building Pada Bangunan Gedung Universitas Pembangunan Jaya Berdasarkan Indikasi Green Building Council Indonesia
}

\author{
Diza Roshaunda ${ }^{1}$, Lala Diana ${ }^{1}$, Lonny Princhika ${ }^{1}$, Shafira Khalisha ${ }^{1}$ Ryan Septiady ${ }^{2}$ \\ ${ }^{1}$ Program Studi Teknik Sipil, Universitas Pembangunan Jaya \\ ${ }^{2}$ Center for Urban Studies, Universitas Pembangunan Jaya \\ ryan.septiady@upj.ac.id
}

\begin{abstract}
Global warming continues to occur due to growing human activities and needs. This of course will have an impact on humans because global warming will be very detrimental. Global warming discussed this time is caused by development activities. Of course this problem is very worrying because development in Indonesia is currently being carried out. With that, knowledge and understanding is needed for construction actors. The suggested solution to overcome this problem is to develop the Green Building concept. The Green Building concept is a good concept to implement because it can help reduce the impact of global warming. We conduct this research to measure whether Universitas Pembangunan Jaya (UPJ) has met the Green Building criteria or not. Measurements in this study were measured based on the Greenship-GBCI standard by conducting direct observations and verification interviews. Based on the data collected and the calculations that have been made on the UPJ building on 41 Greenship criteria, the building obtained a total point of 23 points from 117 maximum points. Thus, it can be concluded that the building of the Pembangunan Jaya University (UPJ) campus does not meet the criteria as a Green Buildinh building based on Greenship-GBCI.

Keywords: Green Building, Greenship-GBCI, Universitas Pembangunan Jaya Campus Building $(U P J)$.
\end{abstract}

\begin{abstract}
Abstrak : Pemanasan global terus terjadi dikarenakan aktivitas dan kebutuhan manusia yang terus bertambah. Hal tersebut tentu saja akan berdampak bagi manusia karena pemanasan global akan sangat merugikan. Pemanasan global yang dibahas kali ini disebabkan oleh kegiatan pembangunan. Tentunya masalah ini sangat mengkhawatirkan karena pembangunan di Indonesia saat ini sedang marak dilakukan. Dengan itu, diperlukan pengetahuan dan pemahaman bagi pelaku kontruksi. Solusi yang disarankan untuk mengatasi masalah tersebut adalah dengan mengembangkan konsep Green Building. Konsep Green Building merupakan konsep yang bagus untuk diterapkan karena dapat banyak membantu mengurangi dampak dari pemanasan global. Penelitian ini kami lakukan untuk mengukur apakah Universitas Pembangunan Jaya (UPJ) sudah memenuhi kriteria Green Building atau belum. Pengukuran dalam penelitian ini diukur berdasarkan standart Greenship-GBCI dengan melakukan pengamatan langsung dan wawancara verifikasi. Berdasarkan data yang terkumpul dan perhitungan yang telah dilakukan pada gedung UPJ terhadap 41 kriteria Greenship, gedung memperoleh total poin sebesar 23 poin dari 117 poin maksimal. Dengan demikian, dapat disimpulkan bahwa gedung kampus Universitas Pembangunan Jaya (UPJ) tidak memenuhi kriteria sebagai bangunan Green Buildinh berdasarkan GreenshipGBCI.
\end{abstract}

Kata Kunci: Bangunan Hijau, Greenship-GBCI, Gedung Kampus Universitas Pembangunan Jaya (UPJ).

\section{PENDAHULUAN}

\section{Latar Belakang}

Indonesia menyumbang 2 gigaton emisi karbon dunia. Dengan itu, Indonesia menempati posisi ke-6 penghasil emisi karbon terbesar menurut riset tentang deforestasi dan degradasi tahun 2011. Kesadaran dunia terus menurun terhadap isu pemanasan global. Pemanasan global terus terjadi dikarenakan aktivitas dan kebutuhan manusia yang terus bertambah. Hal tersebut tentu saja akan berdampak bagi manusia karena pemanasan global akan sangat merugikan. Pemanasan global dapat menyebabkan penipisan lapisan ozon, perubahan iklim yang tidak menentu, dan meningkatnya suhu di bumi. Ada banyak hal yang dapat menyebabkan 
pemanasan global. Diantaranya adalah penyempitan lahan hijau, efek rumah kaca dan pembangunan yang tidak memerhatikan lingkungan.

Pemerintah Indonesia saat ini sedang konsen dalam meningkatkan pembangunan infrastruktur. Pembangunan infrastruktur terus dikembangkan, baik pembangunan irigasi, jalan, ruang-ruang publik, hingga perumahan untuk masyarakat. Pembangunan dapat menimbulkan dampak buruk diantaranya meningkatkan limbah pemcemaran, polusi udara, berkurangnya daerah resapan dan lahan terbuka hijau. Hal tersebut akan berpengaruh terhadap pemanasan global, sehingga sangat penting bagi masyarakat terutama pelaku kontruksi agar lebih mawas terhadap pembangunan yang memerhatikan lingkungan.

Oleh karena itu, diperlukan solusi untuk mengurangi dampak buruk yang akan ditimbulkan. Solusi yang ditawarkan salah satunya adalah dengan menerapkan konsep Green Building. Konsep green building sendiri adalah suatu konsep yang menekankan peningkatan efesiensi sumber daya alam baik penggunaan air dan energi. Selain itu, juga mengefesiensi penggunaan material bangunan guna mengurangi dampak pembangunan terhadap lingkungan dan kesehatan manusia.

Konsep green building ini dapat diterapkan untuk bangunan baru maupun bangunan yang sudah ada. Konsep ini meliputi proses design, proses pembangunan, pemeliharaan hingga renovasi ulang terhadap suatu bangunan. Untuk itu, konsep ini cocok digunakan untuk menangani pemanasan global yang saat ini semakin mengkhawatirkan

\section{Rumusan Masalah}

Beberapa masalah penelitian dapat dirumuskan sebagai berikut :

a. Bagaimana upaya penilaian konsep green building di kampus Universitas Pembangunan Jaya? b. Parameter apa saja yang digunakan untuk mengukur konsep green building di kampus Universitas Pembangunan Jaya?

\section{Tujuan Penelitian}

Penelitian ini bertujuan untuk :

a. Mengetahui apakah Universitas Pembangunan Jaya sudah menerapkan konsep green building sesuai GBCI.

b. Mengukur parameter green building yang diterapkan di kampus Universitas Pembangunan Jaya.

\section{Sistematika Penulisan}

Penulisan ini dibagi menjadi tiga bab dengan sistematika penulisan sebagai berikut:

\section{PENDAHULUAN}

Berisi mengenai latar belakang, formulasi masalah, tujuan dan sistematika penulisan yang berkaitan dengan materi.

\section{METODOLOGI}

Menejelaskan uraian pelaksanaan penelitian mulai dari tahap persiapan, pengumpulan data analisis hingga metode.

\section{PEMBAHASAN}

Menguraikan tentang penilaian kriteria Green Building pada bangunan Gedung Universitas Pembangunan Jaya berdasarkan indikasi Green Building Council Indonesia

\section{KESIMPULAN}

Berisi kesimpulan berdsarkan hasil analisis yang diperoleh sebagai masukan pembaca maupun penelitian selanjutnya.

\section{KAJIAN PUSTAKA Definisi dan Terminologi Green Building}

Menurut Green Building Council Indonesia/GBCI (2010), green building adalah bangunan yang dimana sejak mulai dalam tahap perencanaan,pemmbangunan, pengoperasian sehingga dalam operasional pemeliharaannya memperlihatkan aspekaspek dalam melindungi, dan mengurangi 
penggunaan sumber daya alam, menjaga mutu dari kualitas udara di ruangan, dan memperhatikan kesehatan yang semuanyaberpegang pada kaidah pembangunan yang berkesinambungan .

Menurut Peraturan Menteri Negara Lingkungan Hidup No. 8 Tahun 2010 tentang Kriteria dan Sertifikasi Bangunan Ramah Lingkungan Bab I Pasal 1, bangunan ramah lingkungan (green building) adalah suatu bangunan yang menerapkan prinsip lingkungan dalam perancangan, pembangunan, pengoperasian, dan pengelolaannya dan aspek penting penanganan dampak perubahan iklim.Prinsip lingkungan yang dimaksud adalah prinsip yang mengedepankan dan memperhatikan unsur pelestarian fungsi lingkungan.

Dalam istilah lain green building atau bangunan hijau adalah sebuah bangunan yang didesain untuk mereduksi dampak lingkungan dalam menjaga kesehatan manusia maupun keadaan alam.

\section{Prinsip Green Building}

Berikut ini adalah prinsip-prinsip green building menurut Brenda dan Robert Vale (1991) dalam buku Green Architecture Design For Sustainable Future:

\section{Conserving Energy}

Kunci utama prinsip ini adalah memanfaatkan sumber energi yaitu energy matahari semaksimal mungkin dalam pengoperasian suatu gedung.

\section{Working With Climate}

Kunci utama prinsip ini adalah memanfaatkan kondisi alam, iklim, dan lingkungannya kedalam bentuk pengoperasian gedung.

\section{Respect For Site}

Kunci dari peinsip ini adalah perencanaan yang mengacu pada hubungan antara fungsi bangunan dengan lahan tempat dibangunnya bangunan tersebut. Hal ini dimaksudkan supaya keberadaan bangunan tersebut baik dari segi konstruksi, bentuk, dan pengoperasiannya tidak merusak lingkungan sekitar.

\section{Respect For User}

Kunci dari prinsip ini adalah mengutamakan kenyamanan dan kesehatan penghuninya.

Sistem Rating Greenship untuk Gedung Terbangun Versi 1.0 (Greenship Rating Tools for Existing Building Version 1.0)

Penyusunan Greenship ini didukung oleh World Green Building Council dan dilaksanakan oleh Komisi Rating dari GBCI, terdiri dari 6 (enam) kategori dengan total kriteria prasyarat sebanyak 10 kriteria dan kriteria kredit sebanyak 41 kriteria. Enam kategori Greenship yang dimaksud, yaitu:

a. Tepat Guna Lahan (Appropriate Site Development/ ASD).

b. Efisiensi dan Konservasi Energi (Energy Efficiency andConservation/ EEC).

c. Konservasi Air (Water Conservation/ WAC).

d. Sumber dan Siklus Material (Material Resources and Cycle/ MRC).

e. Kesehatan dan Kenyamanan dalam Ruang (Indoor Health and Comfortl IHC).

f. Manajemen Lingkungan Bangunan (Building Environment Management/ BEM).

\section{Sistem Rating}

Menurut GBCI (2010), rating adalah bagian dari kategori, berisi muatan apa saja yang dinilai, tolok ukur apa saja yang harus dipenuhi, dan berapa nilai poin yang terkandung di dalamnya. (Selanjutnya rating disebut kriteria). Menurut GBCI (2012), ada 3 (tiga) jenis kriteria berbeda yang terdapat dalam Greenship, yaitu:

a. Kriteria prasyarat adalah kriteria yang ada di setiap kategori dan harus dipenuhi sebelum dilakukannya penilaian lebih lanjut berdasarkan kriteria kredit dan kriteria bonus. Apabila salah satu prasyarat tidak dipenuhi, maka kriteria kredit dan 
kriteria bonus dalam kategori yang sama dari gedung tersebut tidak dapat dinilai. Kriteria prasyarat ini tidak memiliki nilai seperti kriteria lainnya.

b. Kriteria kredit adalah kriteria yang ada di setiap kategori dan tidak harus dipenuhi. Pemenuhan kriteria ini tentunya disesuaikan dengan kemampuan gedung tersebut. Bila kriteria ini dipenuhi, gedung yang bersangkutan mendapat nilai dan apabila tidak dipenuhi, gedung yang bersangkutan tidak akan mendapat nilai.

c. Kriteria bonus adalah kriteria yang hanya ada pada kategori tertentu yang memungkinkan pemberian nilai tambahan. Hal ini dikarenakan selain kriteria ini tidak harus dipenuhi, pencapaiannya dinilai cukup sulit dan jarang terjadi di lapangan.

\section{METODOLOGI PENELITIAN}

Metodologi penelitian merupakan sebuah rancangan bagaimana suatu penelitian akan dilakukan. Metodologi tersebut digunakan untuk mendapatkan jawaban terhadap pertanyaan penelitian yang di rumuskan. Jenis metodologi penelitian tentang penilaian kriteria Green Building pada bangunan gedung Universitas Pembangunan Jaya adalah Metodelogi pengumpulan dan analisis data juga studi literatur. yakni mencari referensi teori yang relefan dengan kasus atau permasalahan yang ditemukan.

Referensi ini dapat dicari dari buku, jurnal, artikel laporan penelitian, dan situs-situs di internet. Output dari studi literatur ini adalah terkoleksinya referensi yang relefan dengan perumusan masalah. Tujuannya adalah untuk memperkuat permasalahan serta sebagai dasar teori dalam melakukan studi dan juga menjadi dasar untuk melakukan penelitian ini.

\section{HASIL PENELITIAN DAN ANALISIS Kondisi Gedung UPJ}

Gedung UPJ terletak di pusat Jl. Cendrawasih Raya B7/P Bintaro Jaya,.
Sawah Baru, Kec. Ciputat, Tangerang Selatan, Banten, Indonesia., berdekatan dengan Stasiun KRL Jurang Mangu dan Mall Bintaaro Jaya. Bangunan gedung ini termasuk ke dalam kategori bangunan terbangun (existing building) karena telah berdiri lebih dari 4 tahun.Gedung yang memiliki 8 lantai pada bangunan utama ini memiliki luas lantai keseluruhan kurang lebih $15.092 \mathrm{~m}^{2}$ ini diresmikan oleh SK Menteri Pendidikan Nasional No.38/D/0/2011-Izin Pendirian Universitas Pembangunan Jaya

\section{Syarat Kelayakan Bangunan}

Syarat Kelayakan Bangunan Sebuah gedung harus memenuhi kelayakan sebelum dilakukan proses penilaian. Kelayakan ini ditetapkan di dalam Greenship untuk Gedung Terbangun berdasarkan pada Undang-Undang maupun peraturan yang telah ditetapkan oleh pemerintah. Yang harus dipenuhi tersebut antara lain:

\section{A. Luas Gedung UPJ}

Luas Gedung UPJ keseluruhan adalah $15.092 \mathrm{~m}^{2}$ dengan perincian seperti pada Tabel 1 berikut ini:

Tabel 1. Luas Gedung UPJ

\begin{tabular}{|r|r|r|r|r|r|}
\hline Lantai & $\begin{array}{c}\text { Ruang dengan } \\
\text { Dinding }\end{array}$ & Core & $\begin{array}{r}\text { Ruang } \\
\text { Terbuka }\end{array}$ & Taman & $\begin{array}{c}\text { Total } \\
\left(\mathrm{m}^{2}\right)\end{array}$ \\
\hline 1 & 1,057 & 121 & 1,336 & & 2,514 \\
\hline 2 & 263 & 96 & 1,109 & & 1,468 \\
\hline 3 & 1,704 & 96 & & & 1,800 \\
\hline 4 & 1,194 & 96 & & & 1,290 \\
\hline 5 & 1,790 & 96 & & 446 & 2,332 \\
\hline 6 & 1,800 & 96 & & & 1,896 \\
\hline 7 & 1,800 & 96 & & & 1,896 \\
\hline 8 & 1,800 & 96 & & & 1,896 \\
\hline Total & $\mathbf{1 1 , 4 0 8}$ & $\mathbf{7 9 3}$ & $\mathbf{2 , 4 4 5}$ & $\mathbf{4 4 6}$ & $\mathbf{1 5 , 0 9 2}$ \\
\hline
\end{tabular}

\section{B. Fungsi Gedung Sesuai dengan Peruntukan Lahan Berdasarkan RTRW setempat}

Rencana Tata Ruang Wilayah yang selanjutnya disebut RTRW adalah rencana tata ruang yang bersifat umum dari wilayah kota, yang merupakan penjabaran dari RTRW nasional dan RTRW provinsi, yang berisi tujuan, kebijakan, strategi 
penataan ruang wilayah kota, rencana struktur ruang wilayah kota, rencana pola ruang wilayah kota, penetapan kawasan strategis kota, arahan pemanfaatan ruang wilayah kota, dan ketentuan pengendalian pemanfaatan ruang wilayah kota

Berdasarkan Undang-Undang No. 28 Tahun 2002 tentang Bangunan Gedung, Pasal 6 ayat (1) Pemerintah mewajibkan bangunan gedung dengan fungsi sosial dan budaya harus sesuai dengan peruntukan lokasi yang diatur dalam Peraturan Daerah tentang Rencana Tata Ruang Wilayah Kabupaten/Kota dan lahan peruntukan yang ada di lokasi tapak area Gedung UPJ sudah memenuhi syarat tata ruang sebagai pusat pendidikan.

\section{Kesesuaian Gedung Terhadap Standar Ketahanan Gempa}

Berdasarkan Undang-Undang No. 28 Tahun 2002 tentang Bangunan Gedung, Pasal 18 ayat (1) persyaratan kemampuan struktur bangunan gedung yang stabil dan kokoh sampai dengan kondisi pembebanan maksimum dalam mendukung beban muatan hidup dan beban muatan mati, serta kemampuan untuk mendukung beban muatan yang timbul akibat perilaku alam, seperti gempa bumi. Struktur utama pada Gedung UPJ adalah beton bertulang, dirancang sebagai bangunan tahan gempa, dengan struktur pondasi.

\section{Kesesuaian Gedung Terhadap Standar Keselamatan untuk Kebakaran \\ Berdasarkan Undang-Undang No. 28} Tahun 2002 tentang Bangunan Gedung, Pasal 17 ayat (1) persyaratan keselamatan bangunan gedung meliputi persyaratan kemampuan bangunan gedung untuk mendukung beban muatan, serta kemampuan bangunan gedung dalam mencegah dan menanggulangi bahaya kebakaran dan bahaya petir.

Kemampuan bangunan gedung juga meliputi pengamanan terhadap bahaya kebakaran melalui sistem proteksi pasif dan/atau proteksi aktif. Sistem proteksi aktif yang tersedia di dalam Gedung UPJ adalah alarm kebakaran, sistem hidran, dan pemadam api ringan (APAR). Saat ini alarm kebakaran, sistem hidran, dan pemadam api ringan (APAR) berfungsi dengan baik di setiap lantai gedung.

\section{E. Kesesuaian Gedung Terhadap Standar Aksesibilitas Penyandang Cacat}

Berdasarkan Undang-Undang No. 28 Tahun 2002 tentang Bangunan Gedung, Pasal 31 mengenai penyediaan fasilitas dan aksesibilitas bagi penyandang cacat dan lanjut usia merupakan keharusan bagi semua bangunan gedung, kecuali rumah tinggal. Peraturan ini diperjelas dalam Peraturan Menteri No. 30/PRT/M/2006 tentang Pedoman Teknis Fasilitas dan Aksesibiltas pada Bangunan Gedung dan Lingkungan. Berikut adalah fasilitas di dalam gedung dapat dilihat pada tabel 2 .

Tabel 2. Prinsip Penerapan Fasilitas Bangunan Bagi Kaum Difabel di Gedung RS UPJ

\begin{tabular}{|c|l|c|}
\hline No & \multicolumn{1}{|c|}{$\begin{array}{c}\text { Pedoman } \\
\text { Teknis dan } \\
\text { Aksesibilitas }\end{array}$} & $\begin{array}{c}\text { Penerapan di } \\
\text { gedung UPJ }\end{array}$ \\
\hline 1 & $\begin{array}{l}\text { Ukuran Dasar } \\
\text { Ruang }\end{array}$ & $\begin{array}{c}\text { Sudah Memenuhi } \\
\text { Standar }\end{array}$ \\
\hline 2 & Pintu & $\begin{array}{c}\text { Sudah Memenuhi } \\
\text { Standar }\end{array}$ \\
\hline 3 & Tangga & $\begin{array}{c}\text { Sudah Memenuhi } \\
\text { Standar }\end{array}$ \\
\hline 4 & Lift & $\begin{array}{c}\text { Sudah Memenuhi } \\
\text { Standar }\end{array}$ \\
\hline 5 & Toilet & $\begin{array}{c}\text { Sudah Memenuhi } \\
\text { Standar }\end{array}$ \\
\hline 6 & Wastafel & $\begin{array}{c}\text { Sudah Memenuhi } \\
\text { Standar }\end{array}$ \\
\hline 7 & Telephon & $\begin{array}{c}\text { Sudah Memenuhi } \\
\text { Standar }\end{array}$ \\
\hline 8 & $\begin{array}{l}\text { Perlengkapan } \\
\text { dan Peralatan }\end{array}$ & $\begin{array}{c}\text { Sudah Memenuhi } \\
\text { Standar }\end{array}$ \\
\hline 9 & Perabot & $\begin{array}{c}\text { Sudah Memenuhi } \\
\text { Standar }\end{array}$ \\
\hline 10 & Rambu & $\begin{array}{c}\text { Tidak Memenuhi } \\
\text { Standar }\end{array}$ \\
\hline
\end{tabular}


Berdasarkan hasil pengamatan di lokasi, dapat disimpulkan bahwa Gedung UPJ sudah aksesibel untuk diakses oleh kaum difabel. Setelah dilakukan analisis kelayakan bangunan berdasarkan Perangkat Penilaian Greenship untuk Gedung Terbangun, diperoleh hasil dalam matriks seperti tabel 3 berikut :

Tabel 3 Penilaian Greenship Gedung UPJ

\begin{tabular}{|r|l|c|c|}
\hline No. & \multicolumn{1}{|c|}{ Kriteria } & Layak & Tidak \\
\hline 1. & Luas minimum gedung adalah $2500 \mathrm{~m}^{2}$ & $\sqrt{ }$ & \\
\hline 2. & $\begin{array}{l}\text { Fungsi gedung sesuai dengan } \\
\text { Peruntukan lahan berdasarkan RTRW }\end{array}$ & $\sqrt{ }$ & \\
\hline 3. & $\begin{array}{l}\text { Memiliki dokumen lingkungan, } \\
\text { AMDAL, dan/atau UKL-UPL }\end{array}$ & $\sqrt{ }$ & \\
\hline 4. & $\begin{array}{l}\text { Kesesuaian gedung terhadap } \\
\text { standar keselamatan untuk kebakaran }\end{array}$ & $\sqrt{ }$ & \\
\hline 5. & $\begin{array}{l}\text { Kesesuaian gedung terhadap } \\
\text { standar ketahanan gempa }\end{array}$ & $\sqrt{ }$ & \\
\hline 6. & $\begin{array}{l}\text { Kesesuaian gedung terhadap } \\
\text { standar aksesibilitas difabel }\end{array}$ & $\sqrt{ }$ & \\
\hline
\end{tabular}

\section{Analisis Prasyarat Perangkat Penilaian Greenship Untuk Gedung Terbangun}

Prasyarat (Prerequisite) dalam penilaian Green Building adalah kriteria yang wajib dipenuhi dan diaplikasikan dalam suatu bangunan. Dalam Greenship, apabila kriteria ini tidak dapat dipenuhi, maka kriteria dan tolok ukur yang ada dalam suatu kategori tidak dapat dievaluasi dan proses penilaian Green Building tidak bisa diteruskan. Terdapat 9 (sembilan) prasyarat dalam Greenship untuk Gedung Terbangun yang mewakili 6 (enam) kategori.

Berikut ini adalah matriks hasil wawancara dengan Bapak Ranan Samanya (Head of General Affairs Department). Terkait Prasyarat Perangkat Penilaian Greenship untuk Gedung Terbangun terhadap UPJ (Tabel 4.4)
Tabel 4. Matriks Prasyarat Perangkat Penilaian Greenship untuk Gedung Terbangun

\begin{tabular}{|c|c|c|c|c|c|}
\hline \multirow{2}{*}{ No } & \multirow{2}{*}{\multicolumn{2}{|c|}{ Kategori }} & \multirow{2}{*}{ Prasyarat } & \multicolumn{2}{|c|}{ Memenuhi } \\
\hline & & & & YA & TIDAK \\
\hline \multirow{4}{*}{1} & \multirow{4}{*}{ ASD } & P1 & $\begin{array}{l}\text { Adanya surat } \\
\text { pernyataan } \\
\text { yang memuat } \\
\text { komitmen } \\
\text { manajemen } \\
\text { puncak } \\
\text { mengenai } \\
\text { pemeliharaan } \\
\text { eksterior } \\
\text { bangunan, } \\
\text { manajemen } \\
\text { hama } \\
\text { terpadu/integr } \\
\text { ated pest } \\
\text { management } \\
\text { (IPM), dan } \\
\text { gulma serta } \\
\text { manajemen } \\
\text { habitat sekitar } \\
\text { tapak dengan } \\
\text { menggunakan } \\
\text { bahan-bahan } \\
\text { tidak beracun. }\end{array}$ & & $\sqrt{ }$ \\
\hline & & P2 & $\begin{array}{l}\text { Adanya surat } \\
\text { pernyataan yang } \\
\text { memuat } \\
\text { komitmen } \\
\text { manajemen } \\
\text { puncak untuk } \\
\text { melakukan } \\
\text { berbagai } \\
\text { tindakan dalam } \\
\text { rangka mencapai } \\
\text { pengurangan } \\
\text { pemakaian } \\
\text { kendaraan } \\
\text { bermotor } \\
\text { pribadi, } \\
\text { contohnya car } \\
\text { pooling, feeder } \\
\text { bus, voucher } \\
\text { kendaraan } \\
\text { umum dan } \\
\text { diskriminasi tarif }\end{array}$ & & $\sqrt{ }$ \\
\hline & & & parkir & & \\
\hline & & P3 & $\begin{array}{l}\text { Adanya } \\
\text { kampanye dalam } \\
\text { rangka } \\
\text { mendorong } \\
\text { pengurangan } \\
\text { pemakaian } \\
\text { kendaraan } \\
\text { bermotor pribadi } \\
\text { dengan minimal }\end{array}$ & & $\sqrt{ }$ \\
\hline
\end{tabular}




\begin{tabular}{|c|c|c|c|c|c|}
\hline \multirow{3}{*}{ No } & \multirow{2}{*}{\multicolumn{2}{|c|}{ Kategori }} & \multirow{2}{*}{ Prasyarat } & \multicolumn{2}{|c|}{ Memenuhi } \\
\hline & & & & YA & TIDAK \\
\hline & & & $\begin{array}{l}\text { pemasangan } \\
\text { kampanye } \\
\text { tertulis secara } \\
\text { permanen di } \\
\text { setiap lantai, } \\
\text { antara lain } \\
\text { berupa: stiker, } \\
\text { poster, email. }\end{array}$ & & \\
\hline \multirow{4}{*}{2} & \multirow{4}{*}{ EEC } & \multirow[b]{2}{*}{ P1 } & $\begin{array}{l}\text { Adanya surat } \\
\text { pernyataan } \\
\text { yang memuat } \\
\text { komitmen dari } \\
\text { manajemen } \\
\text { puncak yang } \\
\text { mencakup: } \\
\text { adanya audit } \\
\text { energi, target } \\
\text { penghematan } \\
\text { dan action plan } \\
\text { berjangka waktu } \\
\text { tertentu oleh tim } \\
\text { energi. }\end{array}$ & & $\sqrt{ }$ \\
\hline & & & $\begin{array}{l}\text { Adanya } \\
\text { kampanye } \\
\text { dalam rangka } \\
\text { mendorong } \\
\text { penghematan } \\
\text { energi dengan } \\
\text { minimal } \\
\text { pemasangan } \\
\text { kampanye } \\
\text { tertulis secara } \\
\text { permanen di } \\
\text { setiap lantai, } \\
\text { antara lain } \\
\text { berupa: stiker, } \\
\text { poster, email. }\end{array}$ & & $\sqrt{ }$ \\
\hline & & \multirow[t]{2}{*}{ P2 } & $\begin{array}{l}\text { Memperlihatkan } \\
\text { IKE listrik selama } \\
6 \text { bulan terakhir } \\
\text { sampai lebih } \\
\text { kecil dari IKE } \\
\text { listrik standar } \\
\text { acuan yang } \\
\text { ditentukan oleh } \\
\text { GBC INDONESIA } \\
\text { (Perkantoran } \\
250 \\
\text { kWh/m2.tahun, } \\
\text { Mall } 450 \\
\text { kWh/m2.tahun } \\
\text { dan Hotel atau } \\
\text { Apartemen } 350 \\
\text { kWh/m2.tahun). }\end{array}$ & & $\sqrt{ }$ \\
\hline & & & $\begin{array}{l}\text { Memperlihatkan } \\
\text { adanya } \\
\text { penghematan } \\
\text { energi } 5 \% \text { atau } \\
\text { lebih pada } 6\end{array}$ & & $\sqrt{ }$ \\
\hline
\end{tabular}

\begin{tabular}{|c|c|c|c|c|c|}
\hline \multirow{3}{*}{ No } & \multirow{2}{*}{\multicolumn{2}{|c|}{ Kategori }} & \multirow{2}{*}{ Prasyarat } & \multicolumn{2}{|c|}{ Memenuhi } \\
\hline & & & & YA & TIDAK \\
\hline & & & bulan terakhir. & & \\
\hline \multirow{2}{*}{3} & \multirow{2}{*}{$\begin{array}{c}\text { WA } \\
\text { C }\end{array}$} & \multirow{2}{*}{ P1 } & $\begin{array}{l}\text { Adanya surat } \\
\text { pernyataan } \\
\text { yang memuat } \\
\text { komitmen dari } \\
\text { manajemen } \\
\text { puncak yang } \\
\text { mencakup: } \\
\text { adanya audit } \\
\text { air, target } \\
\text { penghematan } \\
\text { dan action plan } \\
\text { berjangka waktu } \\
\text { tertentu oleh tim } \\
\text { konservasi air. }\end{array}$ & & $\sqrt{ }$ \\
\hline & & & $\begin{array}{l}\text { Adanya } \\
\text { kampanye dalam } \\
\text { rangka } \\
\text { mendorong } \\
\text { konservasi air } \\
\text { dengan minimal } \\
\text { pemasangan } \\
\text { kampanye } \\
\text { tertulis secara } \\
\text { permanen di } \\
\text { setiap lantai, } \\
\text { antara lain } \\
\text { berupa: stiker, } \\
\text { poster, email. }\end{array}$ & & $\sqrt{ }$ \\
\hline \multirow[b]{2}{*}{4} & \multirow[b]{2}{*}{$\begin{array}{c}\text { MR } \\
\mathrm{C}\end{array}$} & \multirow[b]{2}{*}{ P1 } & $\begin{array}{l}\text { Menggunakan } \\
\text { Refrigeran non- } \\
\text { CFC dan Bahan } \\
\text { Pembersih yang } \\
\text { memiliki nilai } \\
\text { Ozone Depleting } \\
\text { Potential (ODP) } \\
\text { kecil, <1 }\end{array}$ & & $\sqrt{ }$ \\
\hline & & & $\begin{array}{l}\text { Apabila masih } \\
\text { menggunakan } \\
\text { CFC sebagai } \\
\text { refrigerant, } \\
\text { diperlukan } \\
\text { adanya Audit } \\
\text { dan rencana } \\
\text { phase out dalam } \\
\text { penggunaan CFC } \\
\text { sebagai } \\
\text { refrigeran dalam } \\
\text { kurun waktu } 3 \\
\text { tahun } \\
\text { mendatang serta } \\
\text { mengurangi } \\
\text { konsumsi CFC } \\
\text { dari kebocoran } \\
\text { dan kerusakan } \\
\text { mesin pendingin } \\
\text { yang dinyatakan }\end{array}$ & $\sqrt{ }$ & \\
\hline
\end{tabular}




\begin{tabular}{|c|c|c|c|c|}
\hline \multirow{5}{*}{ No } & \multirow{3}{*}{ Kategori } & \multirow{2}{*}{ Prasyarat } & \multicolumn{2}{|c|}{ Memenuhi } \\
\hline & & & YA & TIDAK \\
\hline & & $\begin{array}{l}\text { dalam } \\
\text { Refrigerant } \\
\text { Management } \\
\text { System Plan } \\
\text { atau RMS Plan. }\end{array}$ & & \\
\hline & P2 & $\begin{array}{l}\text { Adanya surat } \\
\text { pernyataan yang } \\
\text { memuat } \\
\text { kebijakan } \\
\text { manajemen } \\
\text { puncak yang } \\
\text { memprioritaskan } \\
\text { pembelanjaan } \\
\text { semua material } \\
\text { yang ramah } \\
\text { lingkungan } \\
\text { dalam daftar di } \\
\text { bawah ini: } \\
\text { a. Produksi } \\
\text { regional } \\
\text { b. Bersertifikat } \\
\text { SNI/ISO } \\
\text { /ecolabel } \\
\text { c. Material yang } \\
\text { dapat didaur } \\
\text { ulang (recycle) } \\
\text { d. Material } \\
\text { Bekas (reuse) } \\
\text { e. Material } \\
\text { Terbarukan } \\
\text { (renewable) } \\
\text { f. Material } \\
\text { modular atau } \\
\text { Pre fabrikasi } \\
\text { g. Kayu } \\
\text { bersertifikasi } \\
\text { h. Lampu yang } \\
\text { tidak } \\
\text { mengandung } \\
\text { merkuri }\end{array}$ & & $\sqrt{ }$ \\
\hline & P3 & $\begin{array}{l}\text { i. Insulasi yang } \\
\text { tidak } \\
\text { mengandung } \\
\text { styrene } \\
\text { j. Plafond atau } \\
\text { Partisi yang tidak } \\
\text { mengandung } \\
\text { asbestos } \\
\text { k. Produk kayu } \\
\text { komposit dan } \\
\text { agrifiber } \\
\text { beremisi } \\
\text { formaldehyde }\end{array}$ & & $\sqrt{ }$ \\
\hline
\end{tabular}

\begin{tabular}{|c|c|c|c|c|c|}
\hline \multirow{3}{*}{ No } & \multirow{2}{*}{\multicolumn{2}{|c|}{ Kategori }} & \multirow{3}{*}{\begin{tabular}{l}
\multicolumn{1}{c}{ Prasyarat } \\
rendah \\
I. Produk cat dan \\
karpet yang \\
beremisi VOC \\
rendah
\end{tabular}} & \multicolumn{2}{|c|}{ Memenuhi } \\
\hline & & & & \multirow{2}{*}{ YA } & \multirow{2}{*}{ TIDAK } \\
\hline & & & & & \\
\hline & & \multirow[t]{2}{*}{ P3 } & $\begin{array}{l}\text { Adanya surat } \\
\text { pernyataan yang } \\
\text { memuat } \\
\text { komitmen } \\
\text { manajemen } \\
\text { puncak yang } \\
\text { mengatur } \\
\text { pengelolaan } \\
\text { sampah } \\
\text { berdasarkan } \\
\text { pemisahan } \\
\text { antara: (a). } \\
\text { Sampah Organik; } \\
\text { (b). Sampah } \\
\text { Anorganik, dan } \\
\text { (c). Sampah yang } \\
\text { Mengandung B3 }\end{array}$ & & $\sqrt{ }$ \\
\hline & & & $\begin{array}{l}\text { Adanya } \\
\text { kampanye } \\
\text { dalam rangka } \\
\text { mendorong } \\
\text { perilaku } \\
\text { pemilahan } \\
\text { sampah terpisah } \\
\text { dengan minimal } \\
\text { pemasangan } \\
\text { kampanye } \\
\text { tertulis secara } \\
\text { permanen di } \\
\text { setiap lantai, } \\
\text { antara lain } \\
\text { berupa: stiker, } \\
\text { poster, email. }\end{array}$ & & $\sqrt{ }$ \\
\hline \multirow[t]{2}{*}{5} & \multirow[t]{2}{*}{ IHC } & \multirow[t]{2}{*}{ P1 } & $\begin{array}{l}\text { Adanya surat } \\
\text { pernyataan } \\
\text { yang memuat } \\
\text { komitmen dari } \\
\text { manajemen } \\
\text { puncak untuk } \\
\text { mendorong } \\
\text { minimalisasi } \\
\text { aktifitas } \\
\text { merokok dalam } \\
\text { gedung. }\end{array}$ & $\sqrt{ }$ & \\
\hline & & & $\begin{array}{l}\text { Adanya } \\
\text { kampanye } \\
\text { dilarang } \\
\text { merokok yang } \\
\text { mencakup } \\
\text { dampak negatif } \\
\text { dari merokok } \\
\text { terhadap diri }\end{array}$ & $\sqrt{ }$ & \\
\hline
\end{tabular}




\begin{tabular}{|c|c|c|c|c|c|}
\hline \multirow{3}{*}{ No } & \multirow{2}{*}{\multicolumn{2}{|c|}{ Kategori }} & \multirow{2}{*}{ Prasyarat } & \multicolumn{2}{|c|}{ Memenuhi } \\
\hline & & & & YA & TIDAK \\
\hline & & & $\begin{array}{l}\text { sendiri dan } \\
\text { lingkungan } \\
\text { dengan minimal } \\
\text { pemasangan } \\
\text { kampanye } \\
\text { tertulis secara } \\
\text { permanen di } \\
\text { setiap lantai, } \\
\text { antara lain } \\
\text { berupa: stiker, } \\
\text { poster, email. }\end{array}$ & & \\
\hline 6 & $\begin{array}{l}B E \\
M\end{array}$ & P1 & $\begin{array}{l}\text { Adanya Rencana } \\
\text { operation \& } \\
\text { maintenance } \\
\text { yang mendukung } \\
\text { sasaran } \\
\text { pencapaian } \\
\text { rating-rating } \\
\text { GREENSHIP EB, } \\
\text { dititikberatkan } \\
\text { pada: system } \\
\text { mekanikal \& } \\
\text { elektrikal, sistem } \\
\text { plambing dan } \\
\text { kualitas air, } \\
\text { pemeliharaan } \\
\text { eksterior \& } \\
\text { interior, } \\
\text { purchasing dan } \\
\text { pengelolaan } \\
\text { sampah } \\
\text { Mencakup : } \\
\text { Struktur } \\
\text { organisasi, } \\
\text { Standar } \\
\text { Prosedur } \\
\text { Operasi dan } \\
\text { pelatihan, } \\
\text { program kerja, } \\
\text { anggaran, } \\
\text { laporan berkala } \\
\text { minimum tiap } 3 \\
\text { bulan. }\end{array}$ & $\sqrt{ }$ & \\
\hline
\end{tabular}

\section{Analisis Kesesuaian Kriteria dalam Greenship di Gedung RS UPJ}

Analisis kesesuaian diperoleh dengan cara membandingkan hasil daftar periksa (checklist) dengan kondisi green yang ada dalam Greenship yang digunakan. Setelah dilakukan penyesuaian lalu diperoleh poin untuk setiap kriterianya untuk kemudian dijumlahkan hasilnya menjadi total poin dan akan diperoleh kategori peringkat dalam Greenship.

\section{A. Kategori Tepat Guna Lahan}

Dalam kategori tepat guna lahan, terdapat 8 (delapan) kriteria yang memiliki total nilai maksimum sebesar 16 poin (Tabel 5).

Tabel 5. Ringkasan Kategori Tepat Guna Lahan (ASD)

\begin{tabular}{|c|c|c|c|c|}
\hline \multirow{2}{*}{ No } & \multirow{2}{*}{ Kategori } & \multicolumn{2}{|c|}{ Memenuhi } & \multirow[t]{2}{*}{ POINT } \\
\hline & & YA & TIDAK & \\
\hline \multirow{3}{*}{$\begin{array}{c}\text { ASD } \\
1\end{array}$} & $\begin{array}{l}\text { Terdapat minimal } 5 \\
\text { jenis fasilitas umum } \\
\text { dalam jarak } \\
\text { pencapaian jalan } \\
\text { utama sejauh } 1500 \\
\mathrm{~m} \text { dari tapak. } \\
\end{array}$ & $\sqrt{ }$ & & 1 \\
\hline & $\begin{array}{l}\text { Menyediakan } \\
\text { fasilitas pejalan kaki } \\
\text { yang aman, nyaman } \\
\text { dan bebas dari } \\
\text { perpotongan akses } \\
\text { kendaraan bermotor } \\
\text { untuk } \\
\text { menghubungkan } \\
\text { minimal } 3 \text { fasilitas } \\
\text { umum diatas dan } \\
\text { atau dengan stasiun } \\
\text { transportasi masal. }\end{array}$ & $\sqrt{ }$ & & 1 \\
\hline & $\begin{array}{l}\text { Adanya halte atau } \\
\text { stasiun transportasi } \\
\text { umum dalam } \\
\text { jangkauan } 300 \mathrm{~m} \\
\text { dari gerbang lokasi } \\
\text { bangunan dengan } \\
\text { perhitungan di luar } \\
\text { jembatan } \\
\text { penyeberangan dan } \\
\text { ramp. }\end{array}$ & $\sqrt{ }$ & & 1 \\
\hline $\begin{array}{c}\text { ASD } \\
2\end{array}$ & $\begin{array}{l}\text { Adanya } \\
\text { pengurangan } \\
\text { pemakaian } \\
\text { kendaraan pribadi } \\
\text { bermotor dengan } \\
\text { implementasi dari } \\
\text { salah satu opsi: car } \\
\text { pooling, feeder bus, } \\
\text { voucher kendaraan } \\
\text { umum, atau } \\
\text { diskriminasi tarif } \\
\text { parkir. }\end{array}$ & & $\sqrt{ }$ & 0 \\
\hline $\begin{array}{c}\text { ASD } \\
3\end{array}$ & $\begin{array}{l}\text { Adanya parkir } \\
\text { sepeda yang aman } \\
\text { sebanyak } 1 \text { unit } \\
\text { parkir per } 30 \\
\text { pengguna gedung } \\
\text { tetap. }\end{array}$ & & $\sqrt{ }$ & 0 \\
\hline
\end{tabular}




\begin{tabular}{|c|c|c|c|c|}
\hline \multirow{3}{*}{ No } & \multirow{2}{*}{ Kategori } & \multicolumn{2}{|c|}{ Memenuhi } & \multirow[t]{2}{*}{ POINT } \\
\hline & & YA & TIDAK & \\
\hline & $\begin{array}{l}\text { Apabila memenuhi } \\
\text { butir } 1 \text { di atas dan } \\
\text { menyediakan } 2 \\
\text { tempat ganti baju } \\
\text { khusus dan kamar } \\
\text { mandi khusus } \\
\text { pengguna sepeda } \\
\text { untuk setiap } 25 \\
\text { tempat parkir } \\
\text { sepeda. }\end{array}$ & & $\sqrt{ }$ & 0 \\
\hline \multirow{3}{*}{$\begin{array}{c}\text { ASD } \\
4\end{array}$} & $\begin{array}{l}\text { Adanya area } \\
\text { lansekap berupa } \\
\text { vegetasi (softscape) } \\
\text { yang bebas dari } \\
\text { bangunan taman } \\
\text { (hardscape) yang } \\
\text { terletak di atas } \\
\text { permukaan tanah } \\
\text { seluas minimal 30\% } \\
\text { luas total lahan. }\end{array}$ & & $\sqrt{ }$ & 0 \\
\hline & $\begin{array}{l}\text { Penambahan nilai } 1 \\
\text { poin untuk setiap } \\
\text { penambahan } 10 \% \\
\text { luas tapak untuk } \\
\text { penggunaan area } \\
\text { lansekap. }\end{array}$ & & $\sqrt{ }$ & 0 \\
\hline & $\begin{array}{l}\text { Penggunaan } \\
\text { tanaman lokal yang } \\
\text { berasal dari nursery } \\
\text { lokal dengan jarak } \\
\text { maksimal } 1000 \mathrm{~km} \\
\text { dan tanaman } \\
\text { produktif. }\end{array}$ & & $\sqrt{ }$ & 0 \\
\hline \multirow{2}{*}{$\begin{array}{c}\text { ASD } \\
5\end{array}$} & $\begin{array}{l}\text { Menggunakan } \\
\text { bahan yang nilai } \\
\text { albedo rata-rata } \\
\text { minimal } 0,3 \text { sesuai } \\
\text { dengan perhitungan } \\
\text { pada area atap } \\
\text { gedung yang } \\
\text { tertutup perkerasan. }\end{array}$ & & $\sqrt{ }$ & 0 \\
\hline & $\begin{array}{l}\text { Menggunakan } \\
\text { bahan yang nilai } \\
\text { albedo rata-rata } \\
\text { minimal } 0,3 \text { sesuai } \\
\text { dengan perhitungan } \\
\text { pada area non atap } \\
\text { yang tertutup } \\
\text { perkerasan. }\end{array}$ & & $\sqrt{ }$ & 0 \\
\hline $\begin{array}{c}\text { ASD } \\
6\end{array}$ & $\begin{array}{l}\text { Pengurangan beban } \\
\text { volume limpasan air } \\
\text { hujan dari luas } \\
\text { lahan ke jaringan } \\
\text { drainase kota } \\
\text { sebesar } 50 \% \text { total } \\
\text { volume hujan harian } \\
\text { yang dihitung } \\
\text { berdasarkan } \\
\text { perhitungan debit } \\
\text { air hujan pada bulan }\end{array}$ & & $\sqrt{ }$ & 0 \\
\hline
\end{tabular}

\begin{tabular}{|c|c|c|c|c|}
\hline \multirow{2}{*}{ No } & \multirow{2}{*}{ Kategori } & \multicolumn{2}{|c|}{ Memenuhi } & \multirow[t]{2}{*}{ POINT } \\
\hline & & YA & TIDAK & \\
\hline & basah. & & & \\
\hline \multirow{2}{*}{$\begin{array}{c}\text { ASD } \\
7\end{array}$} & $\begin{array}{l}\text { Memiliki dan } \\
\text { menerapkan SPO } \\
\text { pengendalian } \\
\text { terhadap hama } \\
\text { penyakit dan gulma } \\
\text { tanaman dengan } \\
\text { menggunakan } \\
\text { bahan-bahan tidak } \\
\text { beracun. }\end{array}$ & & $\sqrt{ }$ & 0 \\
\hline & $\begin{array}{l}\text { Penyediaan habitat } \\
\text { satwa non } \\
\text { peliharaan minimal } \\
5 \% \text { dari keseluruhan } \\
\text { area tapak } \\
\text { bangunan, } \\
\text { berdasarkan area } \\
\text { aktifitas hewan } \\
\text { (home range). }\end{array}$ & & $\sqrt{ }$ & 0 \\
\hline \multirow[t]{2}{*}{$\begin{array}{c}\text { ASD } \\
8\end{array}$} & $\begin{array}{l}\text { Melakukan } \\
\text { peningkatan kualitas } \\
\text { hidup masyarakat } \\
\text { sekitar gedung } \\
\text { dengan melakukan } \\
\text { salah satu dari } \\
\text { tindakan berikut: } \\
\text { perbaikan sanitasi, } \\
\text { penyediaan tempat } \\
\text { beribadah, WC } \\
\text { umum, kaki lima dan } \\
\text { pelatihan } \\
\text { pengembangan } \\
\text { masyarakat. }\end{array}$ & $\sqrt{ }$ & & 1 \\
\hline & $\begin{array}{l}\text { Membuka akses } \\
\text { pejalan kaki ke } \\
\text { minimal } 2 \text { orientasi } \\
\text { menuju bangunan } \\
\text { tetangga tanpa } \\
\text { harus melalui area } \\
\text { publik. }\end{array}$ & $\sqrt{ }$ & & 1 \\
\hline
\end{tabular}

B. Kategori Efisiensi dan Konservasi Energi

Dalam kategori efisiensi dan konservasi energi, terdapat 7 (tujuh) kriteria yang memiliki total nilai maksimum sebesar 36 poin (Tabel 6). 
Tabel 6. Ringkasan Efisiensi dan Konservasi Energi (EEC)

\begin{tabular}{|c|c|c|c|c|}
\hline \multirow{2}{*}{ No } & \multirow{2}{*}{ Kategori } & \multicolumn{2}{|c|}{ Memenuhi } & \multirow{2}{*}{ POINT } \\
\hline & & YA & TIDAK & \\
\hline $\begin{array}{c}\text { EEC } \\
1\end{array}$ & $\begin{array}{l}\text { IKE listrik gedung } \\
\text { menunjukkan nilai } \\
\text { di bawah IKE listrik } \\
\text { standar acuan } \\
\text { dalam } 6 \text { bulan } \\
\text { terakhir, maka } \\
\text { setiap } 3 \% \\
\text { penurunan akan } \\
\text { mendapat } 1 \text { poin } \\
\text { tambahan sampai } \\
\text { maksimal } 16 \text { poin. } \\
\text { (Perkantoran } 250 \\
\text { kWh/m2.tahun) }\end{array}$ & & $\sqrt{ }$ & 0 \\
\hline \multirow[t]{3}{*}{$\begin{array}{c}\text { EEC } \\
2\end{array}$} & $\begin{array}{l}\text { Pernah melakukan } \\
\text { komisioning ulang } \\
\text { atau } \\
\text { retrokomisioning } \\
\text { dengan sasaran } \\
\text { peningkatan } \\
\text { kinerja (KW/TR) } \\
\text { pada peralatan } \\
\text { utama MVAC } \\
\text { dalam kurun waktu } \\
1 \text { tahun } \\
\text { sebelumnya. }\end{array}$ & & $\sqrt{ }$ & 0 \\
\hline & $\begin{array}{l}\text { Adanya } \\
\text { komisioning } \\
\text { berkelanjutan } \\
\text { secara berkala } \\
\text { dalam waktu } \\
\text { maksimal } 3 \text { tahun. }\end{array}$ & & $\sqrt{ }$ & 0 \\
\hline & $\begin{array}{l}\text { Bila poin di atas } \\
\text { terpenuhi maka } \\
\text { ada tambahan poin } \\
\text { untuk tesing, } \\
\text { komisioning ulang } \\
\text { atau } \\
\text { retrokomisioning } \\
\text { dengan sasaran } \\
\text { peningkatan } \\
\text { kinerja (KW/TR) } \\
\text { pada Sistem MVAC } \\
\text { (AHU, pompa, } \\
\text { cooling tower) } \\
\text { secara } \\
\text { keseluruhan. }\end{array}$ & & $\sqrt{ }$ & 0 \\
\hline $\begin{array}{c}\text { EEC } \\
3\end{array}$ & $\begin{array}{l}\text { Melakukan } \\
\text { penghematan } \\
\text { dengan lampu yang } \\
\text { memiliki daya } \\
\text { untuk pencahayaan } \\
\text { lebih hemat 20\% } \\
\text { dari daya } \\
\text { pencahayaan yang } \\
\text { tercantum dalam } \\
\text { SNI. }\end{array}$ & $\sqrt{ }$ & & 1 \\
\hline
\end{tabular}

\begin{tabular}{|c|c|c|c|c|}
\hline \multirow{4}{*}{ No } & \multirow{2}{*}{ Kategori } & \multicolumn{2}{|c|}{ Memenuhi } & \multirow{2}{*}{ POINT } \\
\hline & & YA & TIDAK & \\
\hline & $\begin{array}{l}\text { Menggunakan } \\
\text { minimum } 50 \% \\
\text { ballast } \\
\text { frekuensi tinggi } \\
\text { (elektronik) } \\
\text { pada ruang } \\
\text { kerja umum. }\end{array}$ & $\sqrt{ }$ & & 1 \\
\hline & $\begin{array}{l}\text { Melakukan } \\
\text { efisiensi } \\
\text { peralatan yang } \\
\text { memakai } \\
\text { sistem AC yang } \\
\text { dioperasikan } \\
\text { dengan listrik. }\end{array}$ & $\sqrt{ }$ & & 1 \\
\hline $\begin{array}{c}\mathrm{EEC} \\
4\end{array}$ & $\begin{array}{l}\text { Penyediaan } \\
\text { kWh meter } \\
\text { yang meliputi: } \\
\text { sistem tata } \\
\text { udara, sistem } \\
\text { tata cahaya dan } \\
\text { kotak kontak, } \\
\text { sistem beban } \\
\text { lainnya, dan } \\
\text { ruang yang } \\
\text { tidak } \\
\text { dikecualikan } \\
\text { atau } \\
\text { dikondisikan. }\end{array}$ & & $\sqrt{ }$ & 0 \\
\hline & $\begin{array}{l}\text { Adanya } \\
\text { pencatatan } \\
\text { rutin bulanan } \\
\text { hasil pantau } \\
\text { dan koleksi } \\
\text { data pada kWh } \\
\text { meter. } \\
\text { Pencatatan } \\
\text { dilakukan } \\
\text { selama } \\
\text { minimum } 6 \\
\text { bulan terakhir. }\end{array}$ & $\sqrt{ }$ & & 1 \\
\hline & $\begin{array}{l}\text { Mengapresiasi } \\
\text { penggunaan } \\
\text { energi dalam } \\
\text { bentuk Display } \\
\text { Energy yang } \\
\text { ditempatkan di } \\
\text { area publik. }\end{array}$ & & $\sqrt{ }$ & 0 \\
\hline
\end{tabular}




\begin{tabular}{|c|c|c|c|c|}
\hline \multirow{3}{*}{ No } & \multirow{2}{*}{ Kategori } & \multicolumn{2}{|c|}{ Memenuhi } & \multirow{2}{*}{ POIN7 } \\
\hline & & YA & TIDAK & \\
\hline & $\begin{array}{l}\text { Menerapkan } \\
\text { dukungan } \\
\text { teknologi untuk } \\
\text { memonitoring } \\
\text { dan mengontrol } \\
\text { peralatan } \\
\text { gedung melalui } \\
\text { teknologi EMS }\end{array}$ & & $\sqrt{ }$ & 0 \\
\hline $\begin{array}{c}\mathrm{EEC} \\
5\end{array}$ & $\begin{array}{l}\text { Panduan } \\
\text { pengoperasian } \\
\text { dan } \\
\text { pemeliharaan } \\
\text { seluruh sistem } \\
\text { AC (chiller, Air } \\
\text { Handling Unit, } \\
\text { cooling tower). }\end{array}$ & & $\sqrt{ }$ & 0 \\
\hline & $\begin{array}{l}\text { Jika butir } 1 \\
\text { sudah } \\
\text { terpenuhi, } \\
\text { maka ditambah } \\
\text { dengan adanya } \\
\text { Panduan } \\
\text { pengoperasian } \\
\text { dan } \\
\text { pemeliharaan } \\
\text { secara berkala } \\
\text { seluruh sistem } \\
\text { peralatan } \\
\text { lainnya (sistem } \\
\text { transportasi } \\
\text { dalam gedung, } \\
\text { sistem } \\
\text { distribusi air } \\
\text { bersih dan } \\
\text { kotor (pompa) } \\
\text { dan } \\
\text { pembangkit } \\
\text { listrik cadangan }\end{array}$ & & $\sqrt{ }$ & 0 \\
\hline & $\begin{array}{l}\text { Adanya laporan } \\
\text { bulanan selama } \\
\text { minimum } 6 \\
\text { bulan terakhir } \\
\text { untuk kegiatan } \\
\text { pengoperasian } \\
\text { dan } \\
\text { pemeliharaan } \\
\text { sistem gedung }\end{array}$ & $\sqrt{ }$ & & 1 \\
\hline
\end{tabular}

\begin{tabular}{|c|c|c|c|c|}
\hline \multirow{3}{*}{ No } & \multirow{2}{*}{ Kategori } & \multicolumn{2}{|c|}{ Memenuhi } & \multirow{2}{*}{ POINT } \\
\hline & & YA & TIDAK & \\
\hline & $\begin{array}{l}\text { secara tertib } \\
\text { sesuai dengan } \\
\text { format yang } \\
\text { tercantum } \\
\text { dalam panduan } \\
\text { pengoperasian } \\
\text { dan } \\
\text { pemeliharaan. }\end{array}$ & & & \\
\hline $\begin{array}{c}\mathrm{EEC} \\
6\end{array}$ & $\begin{array}{l}\text { Jika } 0.25 \% \text { dari } \\
\text { maximum } \\
\text { power demand } \\
\text { dihasilkan oleh } \\
\text { energi } \\
\text { terbarukan atau } \\
2 \text { kWp energi } \\
\text { terbarukan } \\
\text { yang terpasang. }\end{array}$ & & $\sqrt{ }$ & 0 \\
\hline $\begin{array}{c}\text { EEC } \\
7\end{array}$ & $\begin{array}{l}0.25 \% \\
\text { penurunan } \mathrm{CO} 2 \\
\text { Emission } \\
\text { Reduction } \\
\text { Measures dari } \\
\text { original } \\
\text { emission. }\end{array}$ & & $\sqrt{ }$ & 0 \\
\hline
\end{tabular}

\section{Konservasi Air}

Dalam kategori konservasi air, terdapat 8 (delapan) kriteria yang memiliki total nilai maksimum sebesar 20 poin (Tabel 7).

Tabel 7. Ringkasan Konservasi Air

\begin{tabular}{|c|c|c|c|c|}
\hline No & Kategori & \multicolumn{2}{|c|}{ Memenuhi } & POINT \\
\cline { 3 - 3 } & & YA & TIDAK & \\
\hline WAC 1 & $\begin{array}{c}\text { Adanya sub- } \\
\text { meter } \\
\text { konsumsi air } \\
\text { pada sistem } \\
\text { area publik, } \\
\text { area komersil } \\
\text { dan utilitas } \\
\text { bangunan. }\end{array}$ & & & \\
& & & \\
\hline WAC 2 & $\begin{array}{c}\text { Adanya } \\
\text { standar } \\
\text { prosedur } \\
\text { operasi dan } \\
\text { pelaksanaanny } \\
\text { mengenai } \\
\text { pemeliharaan } \\
\text { dan } \\
\text { pemeriksaan }\end{array}$ & & & \\
& & & \\
& & & \\
\hline
\end{tabular}




\begin{tabular}{|c|c|c|c|c|}
\hline \multirow[t]{2}{*}{ No } & \multirow[t]{2}{*}{ Kategori } & \multicolumn{2}{|c|}{ Memenuhi } & \multirow[t]{2}{*}{ POINT } \\
\hline & & YA & TIDAK & \\
\hline & $\begin{array}{c}\text { sistem } \\
\text { plambing } \\
\text { secara berkala } \\
\text { untuk } \\
\text { mencegah } \\
\text { terjadinya } \\
\text { kebocoran } \\
\text { pemborosan } \\
\text { air dengan } \\
\text { menunjukan } \\
\text { neraca air } \\
\text { dalam } 6 \\
\text { bulan terakhir } \\
\text { untuk } \\
\text { sertifikasi } \\
\text { perdana. }\end{array}$ & & & \\
\hline WAC 3 & $\begin{array}{c}\text { Untuk gedung } \\
\text { dengan } \\
\text { konsumsi air } \\
20 \% \text { diatas } \\
\text { SNI, setiap } \\
\text { penurunan 10\% } \\
\text { mendapat } 1 \\
\text { poin. }\end{array}$ & & $\sqrt{ }$ & 0 \\
\hline WAC 4 & $\begin{array}{c}\text { Menunjukkan } \\
\text { bukti } \\
\text { laboratorium } \\
\text { bulan terakhir } \\
\text { dari air sumbe } \\
\text { primer yang } \\
\text { sesuai dengan } \\
\text { kriteria air } \\
\text { bersih. }\end{array}$ & & $\sqrt{ }$ & 0 \\
\hline WAC 5 & $\begin{array}{c}\text { Menggunakan } \\
\text { air daur ulang } \\
\text { dengan } \\
\text { kapasitas yang } \\
\text { cukup untuk } \\
\text { kebutuhan } \\
\text { make up water } \\
\text { cooling tower. } \\
\text { Tolok Ukur in } \\
\text { hanya berlaku } \\
\text { bagi gedung } \\
\text { yang } \\
\text { menggunakan } \\
\text { cooling tower } \\
\text { pada sistem } \\
\text { pendinginnya. }\end{array}$ & & $\sqrt{ }$ & 0 \\
\hline & $\begin{array}{c}100 \% \\
\text { kebutuhan } \\
\text { irigasi tidak } \\
\text { bersumber dar } \\
\text { sumber air } \\
\text { primer gedung } \\
\text { (PDAM dan ai } \\
\text { tanah). } \\
\end{array}$ & & $\sqrt{ }$ & 0 \\
\hline
\end{tabular}

\begin{tabular}{|c|c|c|c|c|}
\hline \multirow[t]{4}{*}{ No } & \multirow[t]{2}{*}{ Kategori } & \multicolumn{2}{|c|}{ Memenuhi } & \multirow[t]{2}{*}{ POINT } \\
\hline & & $\mathrm{YA}$ & TIDAK & \\
\hline & $\begin{array}{c}\text { Menggunakan } \\
\text { air daur ulang } \\
\text { dengan } \\
\text { kapasitas yang } \\
\text { cukup untuk } \\
\text { kebutuhan } \\
\text { flushing WC, } \\
\text { sesuai dengan } \\
\text { standar WHO } \\
\text { untuk medium } \\
\text { contact }(<100 \\
\text { Fecal Coliform } \\
/ 100 \text { ml). }\end{array}$ & & $\sqrt{ }$ & 0 \\
\hline & $\begin{array}{c}\text { Mempunyai } \\
\text { sistem air daun } \\
\text { ulang yang } \\
\text { keluarannya } \\
\text { setara dengan } \\
\text { standar air } \\
\text { bersih sesuai } \\
\text { Permenkes } \\
\text { No.416 tahun } \\
1990 \text { tentang } \\
\text { Syarat- syarat } \\
\text { dan } \\
\text { Pengawasan } \\
\text { Kualitas Air } \\
\text { untuk } \\
\text { memenuhi } \\
\text { kebutuhan air } \\
\text { bersih. }\end{array}$ & & $\sqrt{ }$ & 0 \\
\hline WAC 6 & $\begin{array}{c}\text { Menggunakan } \\
\text { sistem filtrasi } \\
\text { yang } \\
\text { menghasilkan } \\
\text { air minum yan } \\
\text { sesuai dengan } \\
\text { Permenkes No } \\
492 \text { tahun 201 } \\
\text { tentang } \\
\text { Persyaratan } \\
\text { Kualitas Air } \\
\text { Minum } \\
\text { minimal di } \\
\text { setiap dapur } \\
\text { atau pantry. }\end{array}$ & & $\sqrt{ }$ & 0 \\
\hline WAC 7 & $\begin{array}{c}\text { Konsumsi air } \\
\text { yang } \\
\text { menggunakan } \\
\text { deep well } \\
\text { maksimum } \\
\leq 20 \% \text { dari } \\
\text { konsumsi air } \\
\text { secara } \\
\text { keseluruhan. }\end{array}$ & $\sqrt{ }$ & & 1 \\
\hline
\end{tabular}




\begin{tabular}{|c|c|c|c|c|}
\hline No & Kategori & \multicolumn{2}{|c|}{ Memenuhi } & POINT \\
\cline { 3 - 4 } & & YA & TIDAK & \\
\hline WAC \& & $\begin{array}{c}\geq 50 \% \text { dari } \\
\text { total unit kerar } \\
\text { air pada are } \\
\begin{array}{c}\text { publik } \\
\text { menggunakan } \\
\text { fitur auto stop }\end{array}\end{array}$ & & $\sqrt{ }$ & \\
\hline
\end{tabular}

D. Siklus dan Sumber Daya Material

Dalam kategori siklus dan sumber daya material, terdapat 5 (lima) kriteria yang memiliki total nilai maksimum sebesar 12 poin (Tabel 8).

Tabel 8. Ringkasan Siklus dan Sumber Material (MRC)

\begin{tabular}{|c|c|c|c|c|}
\hline \multirow{2}{*}{ No } & \multirow{2}{*}{ Kategori } & \multicolumn{2}{|c|}{ Memenuhi } & \multirow{2}{*}{ POINT } \\
\hline & & YA & TIDAK & \\
\hline $\begin{array}{c}\text { MRC } \\
1\end{array}$ & $\begin{array}{l}\text { Menggunakan } \\
\text { seluruh sistem } \\
\text { pendingin ruangan } \\
\text { dengan bahan } \\
\text { refrigerant yang } \\
\text { memiliki ODP =0 } \\
\text { (non CFC dan non } \\
\text { HCFC). }\end{array}$ & & $\sqrt{ }$ & 0 \\
\hline $\begin{array}{c}\text { MRC } \\
2\end{array}$ & $\begin{array}{l}\text { Daftar Material } \\
\text { yang Ramah } \\
\text { Lingkungan : A. } \\
\text { 80\% Produksi } \\
\text { regional } \\
\text { berdasarkan total } \\
\text { pembelanjaanmater } \\
\text { ial keseluruhan. B. } \\
\text { 30\% Bersertifikat } \\
\text { SNI / ISO / } \\
\text { ecolabel } \\
\text { berdasarkan total } \\
\text { pembelanjaan } \\
\text { material } \\
\text { keseluruhan. C. 5\% } \\
\text { Material yang } \\
\text { dapat didaur } \\
\text { ulang (recycle) } \\
\text { berdasarkan total } \\
\text { pembelanjaan } \\
\text { material } \\
\text { keseluruhan. D. } \\
\text { 10\% Material } \\
\text { Bekas (reuse) } \\
\text { berdasarkan total } \\
\text { pembelanjaan } \\
\text { material } \\
\text { keseluruhan. E. 2\% } \\
\text { Material } \\
\text { Terbarukan } \\
\text { (renewable) } \\
\text { berdasarkan total } \\
\text { pembelanjaan } \\
\end{array}$ & & $\sqrt{ }$ & 0 \\
\hline
\end{tabular}

\begin{tabular}{|c|c|c|c|c|}
\hline \multirow{2}{*}{ No } & \multirow{2}{*}{ Kategori } & \multicolumn{2}{|c|}{ Memenuhi } & \multirow{2}{*}{ POINT } \\
\hline & & YA & TIDAK & \\
\hline & $\begin{array}{l}\text { material } \\
\text { keseluruhan. F. } \\
\text { 30\% Material } \\
\text { modular atau Pre } \\
\text { fabrikasi } \\
\text { berdasarkan total } \\
\text { pembelanjaan } \\
\text { material } \\
\text { keseluruhan. }\end{array}$ & & & \\
\hline & $\begin{array}{l}\text { Adanya dokumen } \\
\text { yang menjelaskan } \\
\text { pembelanjaan } \\
\text { material sesuai } \\
\text { dengan kebijakan } \\
\text { di atas (minimal 3). }\end{array}$ & & $\sqrt{ }$ & 0 \\
\hline \multirow{4}{*}{$\begin{array}{c}\text { MRC } \\
3\end{array}$} & $\begin{array}{l}\text { Adanya Standar } \\
\text { Prosedur Operasi, } \\
\text { Pelatihan dan } \\
\text { Laporan untuk } \\
\text { mengumpulkan } \\
\text { dan memilah } \\
\text { sampah } \\
\text { berdasarkan jenis } \\
\text { organik dan } \\
\text { anorganik dalam } 6 \\
\text { bulan terakhir } \\
\text { untuk sertifikasi } \\
\text { perdana. }\end{array}$ & & $\sqrt{ }$ & 0 \\
\hline & $\begin{array}{l}\text { Jika telah } \\
\text { melakukan } \\
\text { pemilahan organik } \\
\text { dan anorganik, } \\
\text { melakukan } \\
\text { pengolahan } \\
\text { sampah organik } \\
\text { secara mandiri atau } \\
\text { bekerja sama } \\
\text { dengan badan } \\
\text { resmi pengolahan } \\
\text { limbah organik. }\end{array}$ & & $\sqrt{ }$ & 0 \\
\hline & $\begin{array}{l}\text { Jika telah } \\
\text { melakukan } \\
\text { pemilahan organik } \\
\text { dan anorganik, } \\
\text { melakukan } \\
\text { pengolahan } \\
\text { sampah anorganik } \\
\text { secara mandiri } \\
\text { atau bekerja sama } \\
\text { dengan badan } \\
\text { resmi pengolahan } \\
\text { limbah anorganik } \\
\text { yang memiliki } \\
\text { prinsip 3R } \\
\text { (Reduce, Reuse, } \\
\text { Recycle). }\end{array}$ & & $\sqrt{ }$ & 0 \\
\hline & $\begin{array}{l}\text { Adanya upaya } \\
\text { pengurangan } \\
\text { sampah kemasan } \\
\text { yang terbuat dari } \\
\text { styrofoam dan } \\
\text { non-food grade } \\
\text { plastic. }\end{array}$ & $\sqrt{ }$ & & 1 \\
\hline
\end{tabular}




\begin{tabular}{|c|c|c|c|c|}
\hline \multirow{3}{*}{ No } & \multirow{2}{*}{ Kategori } & \multicolumn{2}{|c|}{ Memenuhi } & \multirow{2}{*}{ POINT } \\
\hline & & YA & TIDAK & \\
\hline & $\begin{array}{l}\text { Adanya upaya } \\
\text { penanganan } \\
\text { sampah dari } \\
\text { kegiatan renovasi } \\
\text { ke pihak ketiga } \\
\text { minimal } 10 \% \text { dari } \\
\text { total anggaran } \\
\text { renovasi dalam } 6 \\
\text { bulan terakhir } \\
\text { untuk sertifikasi } \\
\text { perdana*. }\end{array}$ & & $\sqrt{ }$ & 0 \\
\hline $\begin{array}{c}\text { MRC } \\
4\end{array}$ & $\begin{array}{l}\text { Adanya Standar } \\
\text { Prosedur Operasi, } \\
\text { Pelatihan dan } \\
\text { Laporan } \\
\text { manajemen } \\
\text { pengelolaan } \\
\text { limbah B3 antara } \\
\text { lain: lampu, } \\
\text { baterei, tinta } \\
\text { printer dan } \\
\text { kemasan bekas } \\
\text { bahan pembersih } \\
\text { dalam } 6 \text { bulan } \\
\text { terakhir untuk } \\
\text { sertifikasi perdana. }\end{array}$ & & $\sqrt{ }$ & 0 \\
\hline $\begin{array}{c}\text { MRC } \\
5\end{array}$ & $\begin{array}{l}\text { Adanya Standar } \\
\text { Prosedur Operasi } \\
\text { dan laporan } \\
\text { penyaluran barang } \\
\text { bekas yang masih } \\
\text { dapat } \\
\text { dimanfaatkan } \\
\text { kembali berupa } \\
\text { furniture, } \\
\text { elektronik, dan } \\
\text { suku cadang } \\
\text { melalui donasi atau } \\
\text { pasar barang } \\
\text { bekas dalam } 6 \\
\text { bulan terakhir } \\
\text { untuk sertifikasi } \\
\text { perdana*. }\end{array}$ & $\sqrt{ }$ & & 1 \\
\hline
\end{tabular}

\section{E. Kenyamanan dan Kesehatan Dalam Ruang}

Dalam kategori kenyamanan dan kesehatan dalam ruang, terdapat 8 kriteria yang memiliki total nilai maksimum sebesar 20 poin (Tabel 9).

Tabel 9. Ringkasan Kenyamanan dan Kesehatan dalam Ruang (IHC)

\begin{tabular}{|c|l|c|c|c|}
\hline \multirow{2}{*}{ No } & \multirow{2}{*}{ Kategori } & \multicolumn{2}{|c|}{ Memenuhi } & \multirow{2}{*}{ POINT } \\
\cline { 3 - 4 } & YA & TIDAK & \\
\hline $\begin{array}{c}\text { IHC } \\
1\end{array}$ & $\begin{array}{l}\text { Kualitas udara } \\
\text { ruangan } \\
\text { menunjukan } \\
\text { adanya }\end{array}$ & $\sqrt{ }$ & & 2 \\
\hline
\end{tabular}

\begin{tabular}{|c|c|c|c|c|}
\hline \multirow{2}{*}{ No } & \multirow{2}{*}{ Kategori } & \multicolumn{2}{|c|}{ Memenuhi } & \multirow{2}{*}{ POINT } \\
\hline & & YA & TIDAK & \\
\hline & $\begin{array}{l}\text { introduksi udara } \\
\text { luar minimal } \\
\text { sesuai dengan } \\
\text { SNI } \\
\text { 03-6572-2001 }\end{array}$ & & & \\
\hline $\begin{array}{c}\mathrm{IHC} \\
2\end{array}$ & $\begin{array}{l}\text { Memasang } \\
\text { tanda "Dilarang } \\
\text { Merokok Di } \\
\text { Seluruh Area } \\
\text { Gedung" dan } \\
\text { tidak } \\
\text { menyediakan } \\
\text { bangunan/area } \\
\text { khusus di dalam } \\
\text { gedung untuk } \\
\text { merokok. }\end{array}$ & $\sqrt{ }$ & & 2 \\
\hline & $\begin{array}{l}\text { Ruangan-ruanga } \\
\mathrm{n} \text { dengan } \\
\text { kepadatan } \\
\text { tinggi (seperti } \\
\text { ballroom/ruang } \\
\text { serba guna, } \\
\text { ruang rapat } \\
\text { umum, ruang } \\
\text { kerja umum) } \\
\text { dilengkapi } \\
\text { dengan instalasi } \\
\text { sensor gas } \\
\text { karbondioksida } \\
\text { (CO2). }\end{array}$ & & $\sqrt{ }$ & 0 \\
\hline $\begin{array}{c}\mathrm{IHC} \\
3\end{array}$ & $\begin{array}{l}\text { Ruang parkir } \\
\text { tertutup di } \\
\text { dalam gedung } \\
\text { dilengkapi } \\
\text { dengan instalasi } \\
\text { sensor gas } \\
\text { karbon } \\
\text { monoksida (CO) } \\
\text { yang memiliki } \\
\text { mekanisme } \\
\text { untuk mengatur } \\
\text { jumlah ventilasi } \\
\text { udara luar } \\
\text { sehingga } \\
\text { konsentrasi CO } \\
\text { di dalam } \\
\text { ruangan tidak } \\
\text { lebih dari } 23 \\
\text { ppm. Sensor } \\
\text { diletakkan } 50 \\
\text { cm di atas lantai } \\
\text { dekat exhaust } \\
\text { grille. }\end{array}$ & & $\sqrt{ }$ & 0 \\
\hline
\end{tabular}




\begin{tabular}{|c|c|c|c|c|}
\hline \multirow{2}{*}{ No } & \multirow{2}{*}{ Kategori } & \multicolumn{2}{|c|}{ Memenuhi } & \multirow{2}{*}{ POINT } \\
\hline & & YA & TIDAK & \\
\hline $\begin{array}{c}\mathrm{IHC} \\
4\end{array}$ & $\begin{array}{l}\text { Pengukuran } \\
\text { kualitas udara } \\
\text { dalam ruang } \\
\text { dilakukan secara } \\
\text { random dengan } \\
\text { titik sampel } \\
\text { pada lobi utama, } \\
\text { ruang kerja atau } \\
\text { ruangan yang } \\
\text { disewa tenant. } \\
\text { Pengukuran } \\
\text { dilakukan } \\
\text { minimal } 1 \text { titik } \\
\text { sampel per } 1000 \\
\text { m2 atau jumlah } \\
\text { maksimal } \\
\text { penilaian sampel } \\
\text { adalah } 25 \text { titik } \\
\text { untuk satu } \\
\text { gedung. }\end{array}$ & & $\sqrt{ }$ & 0 \\
\hline \multirow[t]{2}{*}{$\begin{array}{c}\mathrm{IHC} \\
5\end{array}$} & $\begin{array}{l}\text { Pembersihan } \\
\text { filter, coil } \\
\text { pendingin dan } \\
\text { alat bantu VAC } \\
\text { (Ventilation and } \\
\text { Air } \\
\text { Conditioning) } \\
\text { sesuai dengan } \\
\text { jadwal } \\
\text { perawatan } \\
\text { berkala untuk } \\
\text { mencegah } \\
\text { terbentuknya } \\
\text { lumut dan jamur } \\
\text { sebagai tempat } \\
\text { berkembangnya } \\
\text { mikroorganisme } \\
\text { Jadwal } \\
\text { perawatan } \\
\text { sesuai dengan } \\
\text { standar panduan } \\
\text { pabrik. }\end{array}$ & $\sqrt{ }$ & & 2 \\
\hline & $\begin{array}{l}\text { Melakukan } \\
\text { pengukuran } \\
\text { jumlah bakteri } \\
\text { dengan jumlah } \\
3 \\
\text { maksimal } \\
\text { kuman } 700 \\
\text { koloni /m3 } \\
\text { udara dan bebas } \\
\text { kuman } \\
\text { patogen pada } \\
\text { ruangan yang } \\
\text { ditentukan GBC } \\
\text { INDONESIA } \\
\text { (berdasarkan } \\
\text { Keputusan } \\
\text { Menteri } \\
\text { Kesehatan RI } \\
\text { No.1405/Menke } \\
\text { s/SK/XI/2002 } \\
\end{array}$ & & $\sqrt{ }$ & 0 \\
\hline
\end{tabular}

\begin{tabular}{|c|c|c|c|c|}
\hline \multirow{3}{*}{ No } & \multirow{2}{*}{ Kategori } & \multicolumn{2}{|c|}{ Memenuhi } & \multirow{2}{*}{ POINT } \\
\hline & & YA & TIDAK & \\
\hline & $\begin{array}{l}\text { tentang } \\
\text { Persyaratan } \\
\text { Kesehatan } \\
\text { Lingkungan } \\
\text { Kerja } \\
\text { Perkantoran dan } \\
\text { Industri). }\end{array}$ & & & \\
\hline $\begin{array}{c}\mathrm{IHC} \\
6\end{array}$ & $\begin{array}{l}\text { Hasil } \\
\text { pengukuran } \\
\text { menunjukkan } \\
\text { tingkat } \\
\text { pencahayaan } \\
\text { (iluminasi) di } \\
\text { setiap ruang } \\
\text { kerja sesuai } \\
\text { dengan SNI } \\
\text { 03-6197- 2000 } \\
\text { tentang } \\
\text { Konservasi } \\
\text { Energi pada } \\
\text { Sistem } \\
\text { Pencahayaan. }\end{array}$ & $\sqrt{ }$ & & 2 \\
\hline $\begin{array}{c}\mathrm{IHC} \\
7\end{array}$ & $\begin{array}{l}\text { Hasil } \\
\text { pengukuran } \\
\text { menunjukkan } \\
\text { tingkat bunyi di } \\
\text { ruang kerja } \\
\text { sesuai dengan } \\
\text { SNI } \\
\text { 03-6386-2000 } \\
\text { tentang } \\
\text { Spesifikasi } \\
\text { Tingkat Bunyi } \\
\text { dan Waktu } \\
\text { Dengung dalam } \\
\text { Bangunan } \\
\text { Gedung dan } \\
\text { Perumahan }\end{array}$ & $\sqrt{ }$ & & 2 \\
\hline $\begin{array}{c}\mathrm{IHC} \\
8\end{array}$ & $\begin{array}{l}\text { Mengadakan } \\
\text { survei } \\
\text { kenyamanan } \\
\text { pengguna } \\
\text { gedung antara } \\
\text { lain meliputi } \\
\text { suhu udara, } \\
\text { tingkat } \\
\text { pencahayaan } \\
\text { ruang, } \\
\text { kenyamanan } \\
\text { suara, } \\
\text { kebersihan } \\
\text { gedung dan } \\
\text { keberadaan } \\
\text { hama } \\
\text { pengganggu } \\
\text { (pest control). }\end{array}$ & & $\sqrt{ }$ & 0 \\
\hline
\end{tabular}




\begin{tabular}{|l|l|l|l|l|}
\hline \multirow{2}{*}{ No } & \multicolumn{1}{|c|}{ Kategori } & \multicolumn{2}{|c|}{ Memenuhi } & \multirow{2}{*}{ POINT } \\
\cline { 3 - 4 } & $\begin{array}{l}\text { Responden } \\
\text { minimal } \\
\text { sebanyak 30\% } \\
\text { dari total } \\
\text { pengguna } \\
\text { gedung tetap. }\end{array}$ & TIDAK & \\
\hline & & & \\
& & & \\
\hline
\end{tabular}

\section{F. ManajemenLingkungan Bangunan}

Dalam kategori manajemen lingkungan bangunan, terdapat 5 (lima) kriteria yang memiliki total nilai maksimum sebesar 13 poin, Setelah dianalisis, diperoleh hasil bahwa dari semua kriteria dan tolok ukur yang sudah diterapkan, Untuk kategori manajemen lingkungan bangunan, Gedung UPJ tidak memperoleh poin, dikarenakan Gedung UPJ tidak melakukan kajian untuk didaftarkan dan dinilai.

Tabel 4.10. Ringkasan Manajemen Lingkungan Bangunan (BEM)

\begin{tabular}{|c|c|c|c|c|}
\hline \multirow{2}{*}{ No } & \multirow{2}{*}{ Kategori } & \multicolumn{2}{|c|}{ Memenuhi } & \multirow[t]{2}{*}{ POINT } \\
\hline & & YA & TIDAK & \\
\hline \multirow[t]{2}{*}{$\begin{array}{c}\text { BEM } \\
1\end{array}$} & $\begin{array}{l}\text { Aplikasi } \\
\text { inovasi dengan } \\
\text { meningkatkan } \\
\text { kualitas } \\
\text { bangunan } \\
\text { secara } \\
\text { kuantitatif, } \\
\text { contoh: ASD 4, } \\
\text { EEC 1, WAC 3, } \\
\text { dan IHC 4 } \\
\text { sehingga } \\
\text { terjadi } \\
\text { peningkatan } \\
\text { efisiensi } \\
\text { melebihi batas } \\
\text { maksimum } \\
\text { yang ditentukan } \\
\text { pada rating } \\
\text { yang } \\
\text { bersangkutan. }\end{array}$ & & $\sqrt{ }$ & 0 \\
\hline & $\begin{array}{l}\text { Aplikasi } \\
\text { inovasi dengan } \\
\text { melakukan } \\
\text { pendekatan } \\
\text { manajemen } \\
\text { seperti } \\
\text { mendorong } \\
\text { perubahan } \\
\text { perilaku, contoh } \\
\text { ASD 2 dan }\end{array}$ & & $\sqrt{ }$ & 0 \\
\hline
\end{tabular}

\begin{tabular}{|c|c|c|c|c|}
\hline \multirow{3}{*}{ No } & \multirow{2}{*}{ Kategori } & \multicolumn{2}{|c|}{ Memenuhi } & \multirow[t]{2}{*}{ POINT } \\
\hline & & YA & TIDAK & \\
\hline & $\begin{array}{l}\text { ASD } 8 \text { dan } \\
\text { MRC 2, } 3 \text { dan } \\
4, \text { sehingga } \\
\text { terjadi } \\
\text { peningkatanefis } \\
\text { iensi pada } \\
\text { rating lain. }\end{array}$ & & & \\
\hline & $\begin{array}{l}\text { Tersedianya } \\
\text { dokumen } \\
\text { Design Intent } \\
\text { dan Owner's } \\
\text { Project } \\
\text { Requirement } \\
\text { berikut } \\
\text { perubahan-peru } \\
\text { bahannya yang } \\
\text { terjadi } \\
\text { selama masa } \\
\text { revitalisasi dan } \\
\text { operasional. } \\
\end{array}$ & & $\sqrt{ }$ & 0 \\
\hline $\begin{array}{c}\text { BEM } \\
2\end{array}$ & $\begin{array}{l}\text { Tersedianya } \\
\text { dokumen As } \\
\text { Built Drawing, } \\
\text { spesifikasi } \\
\text { teknis dan } \\
\text { manual untuk } \\
\text { operasional dan } \\
\text { pemeliharaan } \\
\text { peralatan } \\
\text { (genset, } \\
\text { transportasi } \\
\text { dalam gedung, } \\
\text { AC dan cooling } \\
\text { tower) berikut } \\
\text { perubahan- } \\
\text { perubahannya } \\
\text { yang terjadi } \\
\text { selama masa } \\
\text { revitalisasi dan } \\
\text { operasional. }\end{array}$ & & $\sqrt{ }$ & 0 \\
\hline \multirow[t]{2}{*}{$\begin{array}{c}\text { BEM } \\
3\end{array}$} & $\begin{array}{l}\text { Adanya satu } \\
\text { struktur yang } \\
\text { terintegrasi di } \\
\text { dalam struktur } \\
\text { operasional } \\
\text { dan } \\
\text { pemeliharaan } \\
\text { gedung yang } \\
\text { bertugas } \\
\text { menjaga } \\
\text { penerapan } \\
\text { prinsip } \\
\text { sustainability/gr } \\
\text { een building. }\end{array}$ & & $\sqrt{ }$ & 0 \\
\hline & $\begin{array}{l}\text { Minimal } \\
\text { terlibat seorang } \\
\text { Greenship } \\
\text { Profesional } \\
\text { dalam } \\
\text { operational \& } \\
\text { maintenance } \\
\text { bekerja penuh } \\
\text { waktu (full }\end{array}$ & & $\sqrt{ }$ & 0 \\
\hline
\end{tabular}




\begin{tabular}{|c|c|c|c|c|}
\hline \multirow{3}{*}{ No } & \multirow{2}{*}{ Kategori } & \multicolumn{2}{|c|}{ Memenuhi } & \multirow[t]{2}{*}{ POINT } \\
\hline & & YA & TIDAK & \\
\hline & time). & & & \\
\hline $\begin{array}{c}\text { BEM } \\
4\end{array}$ & $\begin{array}{l}\text { Untuk } \\
\text { bangunan yang } \\
\text { dipakai sendiri, } \\
\text { memiliki SPO } \\
\text { dan Training } \\
\text { yang } \\
\text { mencakup } \\
\text { upaya-upaya } \\
\text { untuk } \\
\text { memenuhi } \\
\text { kriteria-kriteria } \\
\text { dalam } \\
\text { GREENSHIP } \\
\text { untuk Gedung } \\
\text { Terbangun } \\
\text { minimum 1 } \\
\text { rating dalam } \\
\text { tiap kategori } \\
\text { ASD, EEC, } \\
\text { WAC, IHC dan } \\
\text { MRC. }\end{array}$ & & $\sqrt{ }$ & 0 \\
\hline $\begin{array}{c}\text { BEM } \\
5\end{array}$ & $\begin{array}{l}\text { Adanya jadwal } \\
\text { berkala } \\
\text { minimum tiap } 6 \\
\text { bulan dan } \\
\text { program } \\
\text { pelatihan } \\
\text { dalam } \\
\text { pengoperasian } \\
\text { dan } \\
\text { pemeliharaan } \\
\text { untuk tapak, } \\
\text { energi, air, } \\
\text { material dan } \\
\text { HSES (Health } \\
\text { Safety } \\
\text { Environmental } \\
\text { and Security). }\end{array}$ & & $\sqrt{ }$ & 0 \\
\hline & $\begin{array}{l}\text { Adanya bukti } \\
\text { pelaksanaan } \\
\text { pelatihan untuk } \\
\text { tapak, energi, } \\
\text { air, material } \\
\text { dan program } \\
\text { HSES berikut } \\
\text { dengan evaluasi } \\
\text { dari pelatihan } \\
\text { tersebut. }\end{array}$ & & $\sqrt{ }$ & 0 \\
\hline
\end{tabular}

\section{KESIMPULAN}

Dari hasil penyajian data dan pembahasan sebelumnya maka dapat disimpulkan bahwa

Gedung Universitas Pembangunan Jaya dari luas gedung, fungsi gedung yang sesuai dengan peruntukan lahan RTRW, kesesuaian gedung terhadap estándar ketahanan gempa, kesesuaian gedung terhadap estándar keselamatan untuk kebakaran, dan kesesuaian gedung terhadap estándar aksesibilitas penyandang cacat sudah layak sesuai Undang-Undang maupun peraturan yang telah ditetapkan oleh pemerintah. Universitas Pembangunan Jaya belum menerapkan konsep green building sesuai GBCI.

Dari 41 kriteria yang ada dalam kategori Greenship GBCI, Gedung UPJ memperoleh total poin sebesar 23 poin dari 117 poin maksimal, sehingga bisa dikatakan bangunan gedung UPJ menurut GBCI belum memenuhi prasyarat Greenship.

\section{DAFTAR PUSTAKA}

1. Badan Standarisasi Nasional. 2004. SNI 16-7062-2004 tentang Pengukuran Intensitas Penerangan di Tempat Kerja. Badan Standarisasi Nasional, Jakarta.

2. Badan Standarisasi Nasional. 2000. SNI 03-6197-2000 tentang Konservasi Energi pada Sistem Pencahayaan. Badan Standarisasi Nasional, Jakarta.

3. Badan Standarisasi Nasional. 2000. SNI 03-6196-2000 tentang Prosedur Audit Energi Pada Pembangunan Gedung. Badan Standarisasi Nasional, Jakarta.

4. N Firnando

https://jurnal.usu.ac.id/index.php/jts/ar ticle/view/16608 (diakses pada 10 April 2019)

5. Peraturan Gubernur Provinsi DKI Jakarta No. 38 Tahun 2012 tentang Bangunan Gedung Hijau

6. Peraturan Menteri Pekerjaan Umum No. 5/PRT/M/2008 mengenai Ruang Terbuka Hijau (RTH) Pasal 2.3.1 tentang Kriteria Vegetasi untuk Pekarangan

7. R Waluyo http://puslit2.petra.ac.id/ejournal/inde x.php/uaj/article/view/17520 (diakses pada 17 Maret 2019 
8. Undang-Undang No. 28 Tahun 2002 tentang Bangunan Gedung

9. Undang-Undang No. 32 Tahun 2009 tentang Perlindungan dan Pengelolaan Lingkungan Hidup 